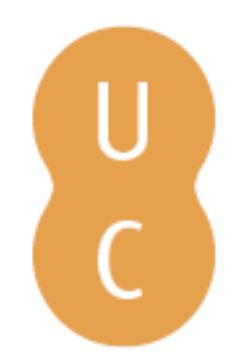

\title{
pompalina
}

\section{Severe complications following low-dose application of methotrexate}

\author{
Autor(es): $\quad$ Buschmann, C.; Tsokos, M.; Schulz, F.
} Publicado por: Imprensa da Universidade de Coimbra; International Academy of Legal

URL

persistente: URI:http://hdl.handle.net/10316.2/31830

DOI: DOI:http://dx.doi.org/10.14195/978-989-26-0173-1_46

Accessed : $\quad$ 26-Apr-2023 15:55:17

A navegação consulta e descarregamento dos títulos inseridos nas Bibliotecas Digitais UC Digitalis, UC Pombalina e UC Impactum, pressupõem a aceitação plena e sem reservas dos Termos e Condições de Uso destas Bibliotecas Digitais, disponíveis em https://digitalis.uc.pt/pt-pt/termos.

Conforme exposto nos referidos Termos e Condições de Uso, o descarregamento de títulos de acesso restrito requer uma licença válida de autorização devendo o utilizador aceder ao(s) documento(s) a partir de um endereço de IP da instituição detentora da supramencionada licença.

Ao utilizador é apenas permitido o descarregamento para uso pessoal, pelo que o emprego do(s) título(s) descarregado(s) para outro fim, designadamente comercial, carece de autorização do respetivo autor ou editor da obra.

Na medida em que todas as obras da UC Digitalis se encontram protegidas pelo Código do Direito de Autor e Direitos Conexos e demais legislação aplicável, toda a cópia, parcial ou total, deste documento, nos casos em que é legalmente admitida, deverá conter ou fazer-se acompanhar por este aviso.

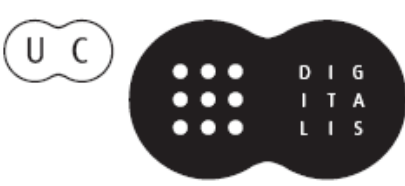




\section{Duarte Nuno Vieira Anthony Busuttil \\ Denis Cusack • Philip Beth}
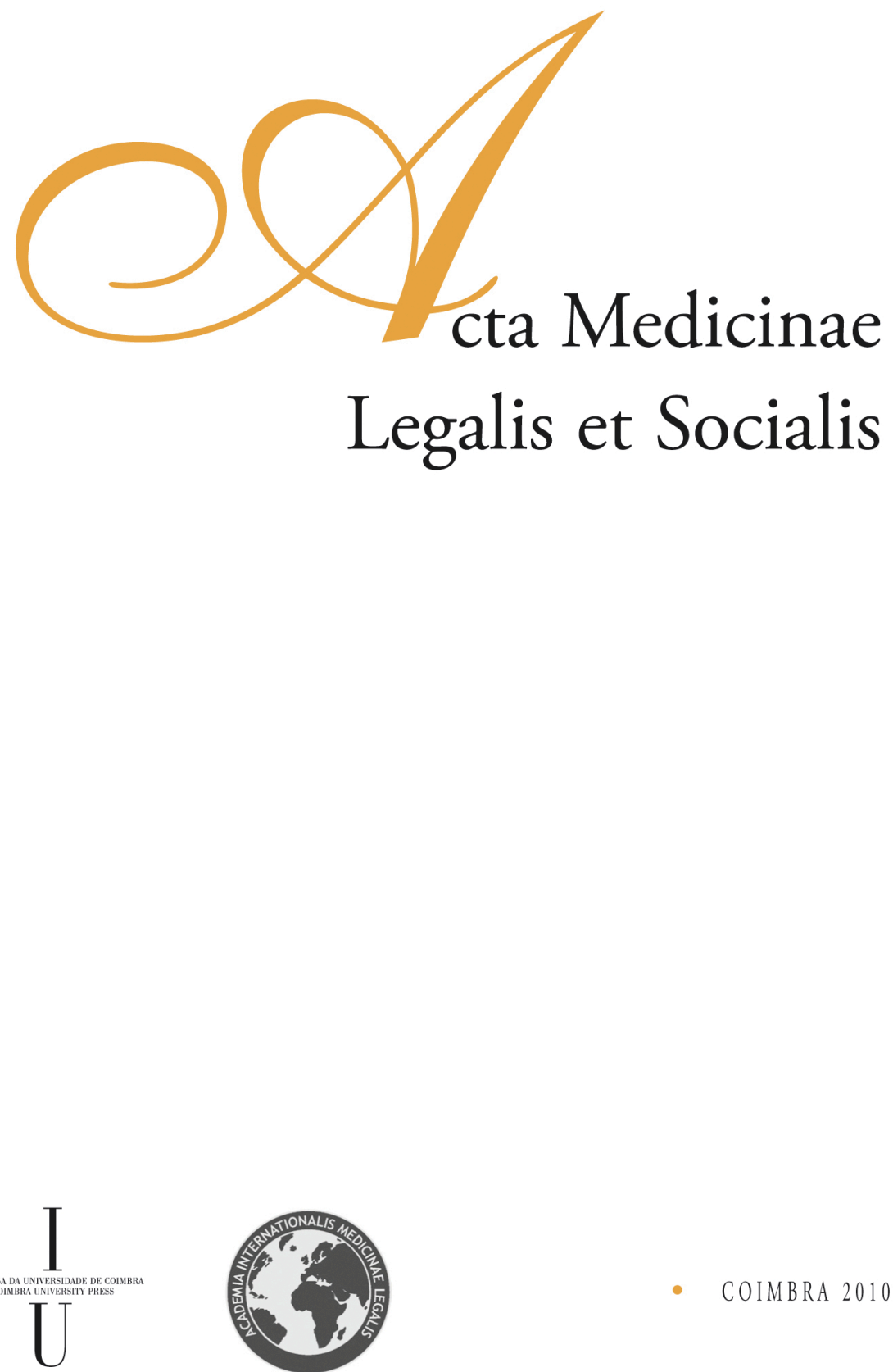
C. Buschmann ${ }^{1}$, M. Tsokos ${ }^{1}$, F. Schulz ${ }^{2}$

${ }^{1}$ Institute of Legal Medicine and Forensic Sciences, University Medicine Charité, Berlin, Germany

${ }^{2}$ Department of Forensic Medicine, University Medical Centre Hamburg-Eppendorf, Hamburg, Germany

\title{
SEVERE COMPLICATIONS FOLLOWING LOW-DOSE APPLICATION OF METHOTREXATE
}

\begin{abstract}
Methotrexate is a folate antagonist used to treat malignant tumors, mostly combined with other cytostatic drugs and/or radiotherapy. However, it can also be applied for therapy of chronic polyarthritis and other joint-destroying rheumatic diseases. Lowdose methotrexate $(15-25 \mathrm{mg} / \mathrm{week})$ is indicated as the basic therapeutic agent for these diseases. Even this low-dose therapy may damage bone marrow and thus cause potentially lethal infections. In the context of basic antirheumatic drug therapy, the use of methotrexate requires strict indications and frequent laboratory follow-ups. Interactions with other pharmaceutical agents must also be considered.
\end{abstract}

\section{Introduction}

Methotrexate (MTX) is a folate antagonist used in combined chemotherapy or chemoradiotherapy regimens for treatment of malignant tumors, especially leukemias with central nervous system manifestations (1). Other indications are rheumatoid arthritis and other chronic-rheumatic illnesses, but doses are lower than those used for neoplastic diseases $(2,3)$. Even this therapeutic dosage (low-dose therapy) can cause substantial side effects largely involving the hematopoietic system. Hepatotoxic effects, interstitial ("atypical") pneumonia and mucositis may also occur $(4,5,6)$. These unwanted side effects appear mainly in the presence of factors that increase the accumulation and thus potentiate MTX toxicity. These factors include pre-existing infections and simultaneous therapy with more than five drugs as well as renal insufficiency, since MTX is renally excreted (7). The minimum lethal dose is $10 \mathrm{mg} /$ week for patients with renal insufficiency. Even slightly reduced renal function can prolong the radioactive half-life of MTX (8) and thus lead to intoxication.

\section{Material and Methods}

We evaluated five cases of death from the Department of Forensic Medicine, University Medical Centre Hamburg-Eppendorf, Germany, where MTX application in low-dosages was performed. 


\section{Clinical appearance}

Chronic rheumatoid arthritis is often an illness of the elderly (9), thus mainly affecting multimorbid patients with various pre-existing internal diseases such as diabetes mellitus, arterial hypertension, (compensated) cardiac and/or renal insufficiency, coronary heart disease and arrhythmias. These pre-existing diseases may complicate the clinical diagnosis of MTX intoxication under low-dose therapy, since symptoms of generalized immunodeficiency may also be due to advanced age or associated geriatric diseases and conditions, e.g., hematologic conditions. A characteristic finding is the rapidly deteriorating general condition of the patient. Rapidly decreasing thrombocyte and leukocyte levels lead to pancytopenia and agranulocytosis with toxic bone marrow depression, mainly accompanied by atypical pneumonia and nonspecific neurological symptoms such as confusion. Patients may also develop hemorrhagic inflammation of the gastrointestinal tract such as duodenitis, glossitis and stomatitis, followed by dysphagia and petechial bleedings in the oral cavity. Death is usually due to fulminant sepsis.

\section{Autopsy}

Common autopsy findings are septic multiple organ failure with shock lungs, hemorrhagic pneumonia, brain oedema, fibrinous pericarditis and ubiquitous petechial bleedings (due to disseminated intravasal coagulation). Noteworthy is the lack of immunoreactions.

\section{Histology of bone marrow}

Histological examination typically shows high-grade insufficiency with hypocellular bone marrow, reduced thrombopoiesis and erythropoiesis and severely depressed granulopoiesis with only scattered immature stages indicative of toxic marrow damage (Fig.1). Chloroacetate esterase reaction reveal almost no mature cells (Fig.2), a marked left shift of granulocytopoiesis with a preponderance of immature leukocytes is also noticeable (Fig. 3).

\section{Histology of the lungs}

Histological lung sections show fibrinous plaques in the alveoli and disseminated hemorrhagic and fibrinous pneumonic infiltrates with a distinctly noncellular appearance. There is no cellular inflammatory reaction (Fig 4).

\section{Conclusions}

Following current guidelines (10), a detailed history and a hemogram must be obtained before initiating therapy with MTX. This applies particularly to liver parameters as well as creatinine, alkaline phosphatase and thrombocyte levels. Under current MTX therapy, hemograms must be taken at intervals of 4-8 weeks to adapt MTX dosages. Caution is urged to avoid accidental MTX overdosing, which can occur easily, since MTX is mostly given to patients who have long been receiving nonsteroidal antirheumatics (NSAR). Simultaneous medication with MTX and NSAR may lead to an excessively 
high concentration of MTX in blood. This may be explained by the renal excretion of MTX (7) and the analgesic nephropathy attributed to long-term NSAR intake (11). Furthermore, chronic rheumatic diseases are treated with corticoid drugs, which are also regarded as potentially nephrotoxic; chronic renal insufficiency is a relative contraindication for their application (12). The pancytopenia and toxic agranulocytosis resulting from renal decompensation might be clinically detected, but subsequent inflammations will often remain uncontrollable and resistant to antibiotics at this stage. MTX is known to interact with different antibiotics (13). According to the literature, aminoglycoside antibiotics are especially likely to potentiate the toxic effects of MTX and are associated with ototoxicity and nephrotoxicity triggered by electrolyte shifts $(14,15)$. Thus renal insufficiency may also be induced or worsened. MTX overdoses should therefore be treated causally by folate administration and forced diuresis. Severe courses require haemodialysis, hemoperfusion, plasma exchange and treatment with Granulokine. Despite the above complications, antibiotic therapy should be initiated. Frequent monitoring of relevant parameters is essential to promptly control the side effects of MTX therapy. Furthermore, low-dose MTX therapy should be restricted to specialists - some deaths are at least partially attributable to iatrogenic complications. MTX therapy requires regular monitoring before and during its application as well as necessary dose adjustments.

\section{References}

1. KLEIHUES P, KIESSLING M, WIESTLER OD, AGUZZI A. Zentrales Nervensystem [Central Nervous System]. In: Böcker W, Denk H, Heitz U (Eds.): Pathologie. Munich / Jena, Urban \& Fischer Publishing House: 296, 2001.

2. BERTHELOT JM, MAUGARS Y, HAMIDOU M et al. Pancytopenia and severe cytopenia induced by lowdose methotrexate. Eight case-reports and a review of one hundred cases from the literature (with twenty-four deaths). Rev Rhum 62: 477-486, 1995.

3. CALVO-ROMERO JM. Severe pancytopenia associated with low-dose Methotrexate therapy for rheumatoid arthritis. Ann Pharmacother 35: 1575-1577, 2001.

4. BRUYN GAW, VELTHUYSEN E, JOOSTEN P, HOUTMAN PM. Pancytopenia related eosinophilia in rheumatoid arthritis: a specific methotrexate phenomenon? J Rheumatol 22: 1373-1376, 1995.

5. MACKINNON SK, STARKEBAUM G, WILKENS RF. Pancytopenia associated with low dose pulse methotrexate in the treatment of rheumatoid arthritis. Sem Arthritis Rheumat 15: 119-126, 1985.

6. SOSTMAN HD, MATTHAY RA, PUMAN CE, SMITH GJW. Methotrexate-induced pneumonitis. Medicine 55: 371-388, 1976.

7. TETT SE, TRIGGS EJ. Use of methotrexate in older patients. A risk-benefit assessment. Drugs Aging 9: 458-471, 1996.

8. GUITIERREZ-URENA S, MOLINA JF, GARCIA CO, CUELLAR ML, ESPINOZA LR. Pancytopenia secondary to methotrexate therapy in rheumatoid arthritis. Arthritis Rheumat 39: 272-276, 1996.

9. BUSCHMANN C, THEILE A, TSOKOS M, PÜSCHEL K, SCHULZ F. Todesfälle nach lowdose-Therapie mit Methotrexat (MTX) [Fatalities after low-dose therapy with methotrexate]. Rechtsmedizin 2: 89-93, 2007.

10. American College of Rheumatology ad hoc on Clinical Guidelines, Guidelines for monitoring drug therapy in rheumatoid arthritis. Arthritis Rheumat 39: 723-731, 1996. 
11. FRENIA M, LONG K. Methotrexate and nonsteroidal antiinflammatory drug interactions. Ann Pharmacother 26: 234-237, 1992.

12. LÜLLMANN H, MOHR K, WEHLING M. Endokrine Drüsen [Endocrine Glands]. In: Lüllmann H, Mohr K, Wehling M (Eds.): Pharmakologie und Toxikologie [Pharmacology and Toxicology]. Stuttgart / New York, Georg Thieme Publishing House 373, 2003.

13. NANKE Y, KOTAKE S, AKAMA H, TOMII M, KAMATANI N. Pancytopenia and Colitis with Clostridium difficile in a rheumatoid arthritis patient taking Methotrexate, antibiotics and non-steroidal anti-inflammatory drugs. Clin Rheumatol 20: 73-75, 2001.

14. LÜLLMANN H, MOHR K, WEHLING M. Antiinfektiöse Wirkstoffe [Antiinfectious Agents]. In: Lüllmann H, Mohr K, Wehling M (Eds.): Pharmakologie und Toxikologie [Pharmacology and Toxicology]. Stuttgart / New York, Georg Thieme Publishing House 436., 2003.

15. OHOSONE Y, OKANO Y, KAMEDA H et al. Toxicity of low-dose Methotrexate in rheumatoid arthritis - clinical characteristics in patients with MTX-induced pancytopenia and interstitial pneumonitis. Ryumachi (Rheumatism) 37: 16-23, 1997.

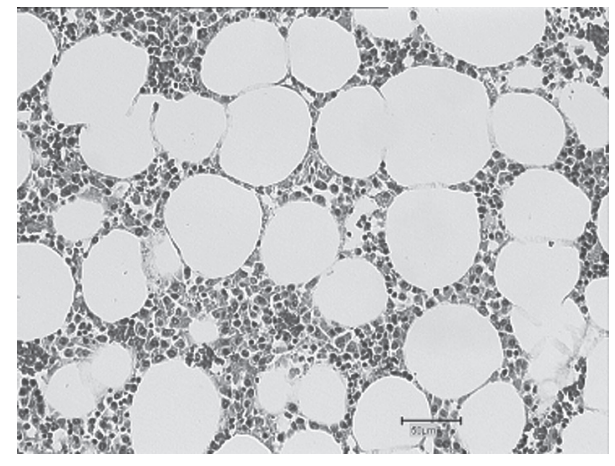

Figure 1 - Defective erythropoiesis and reduced granulocytopoiesis. No metamyelocytes, stab cells or mature granulocytes. Only scattered megakaryoblasts and histiocytes are detectable

(HE x 50).

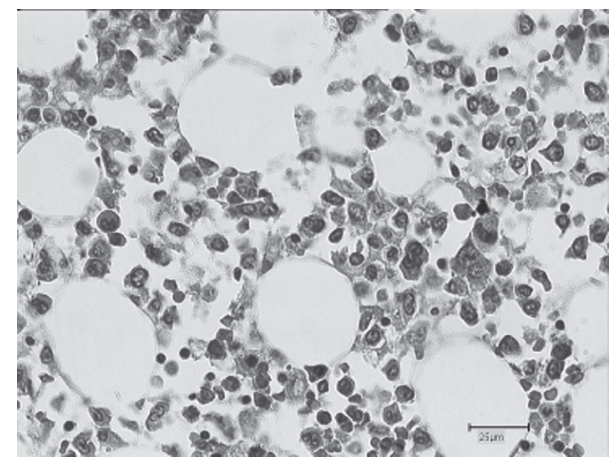

Figure 3 - Marked left shift of erythro-, granulo- and thrombopoiesis with defects mainly in granulopoiesis (HE x 100).

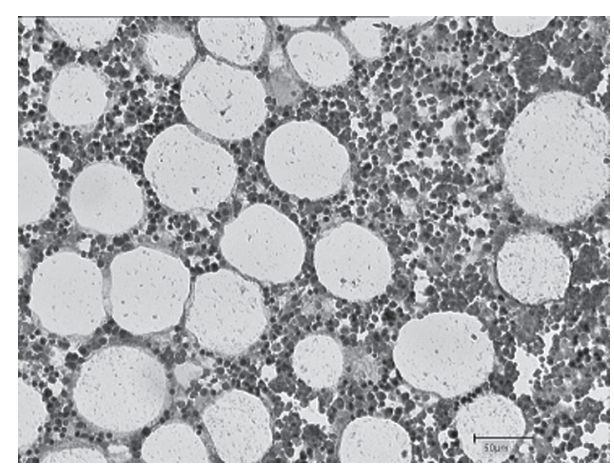

Figure 2 - Marked reduction of granulopoiesis and thrombopoiesis; lack of stab cells and polymorphs. Petechial bleedings on the right side of the screen (HE x 50).

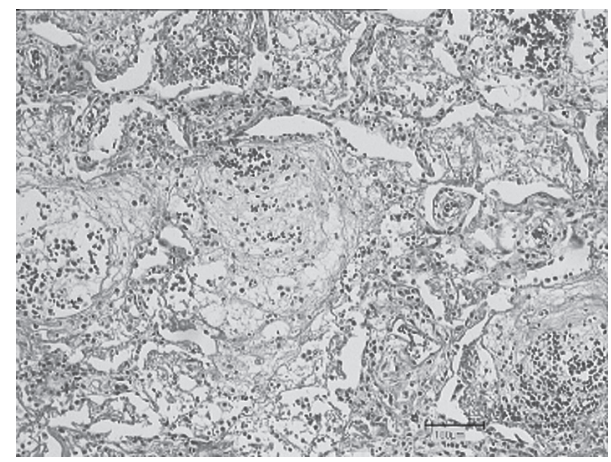

Figure 4 - chronic florid, partly organized pneumonia with loose, fibrinous mesenchymal structures in the alveoli. Few inflammatory cells with no mature granulocytes in the exudate (HE x 25). 